\title{
Representation of Female Attributes in Chinese Proverbs
}

\section{Introduction}

Proverbs are generally known as part of the cultural knowledge and discourse and are employed as shortcuts to express 'pearls of wisdom', or just a relevant commentary drawn from an elusive 'common knowledge', often expressed through a rhymed and humorous play on words. A proverb follows Darwinian laws and survives in the spoken and written form within a linguistic unit on the strength of its cultural and temporal relevance, sometimes wrapped in a timeless comedic envelope.

In the literature, proverbs are taken as 'culturally confirmed frozen texts of a prototypical practice used as an illocution over a categorical action in a setting for a projected view of life' (Bhuvaneswar 2015). They function as a means of transfer of indigenous knowledge and wisdom from generation to generation and 'connect the human and the world and they are the way language gives the opportunity to the human to impact the world' (Shedrovitsky/Rozin 1967:12). Dominguez (2010:50) claims that 'values and beliefs are codified and manifested in all aspect of linguistic communication, such as proverbs, popular expressions, shared vocabulary, oral traditions, conversational rules and modes of interaction, and even linguistic modes of creativity.' Taylor (1996:1 - 2) states that 'a proverb is wise, it belongs to many people; it is ingenious in form and idea.'

Proverbs have been analysed by many linguists and scholars spanning a range of topics and research foci. For instance, Mieder $(2004,2008)$ looked into the nature of proverbs; Goodwin and Wenzel (1981), Honeck and Kibler (1984), Kemper (1981), and Pasamanick (1985) studied proverbs in relation to the their cognitive aspect; Lieber (1984) and Yankah (1994) focused on the pragmatics of 
proverbs; Paltridge (1994) and Tyler (1994) analysed the historical and cultural contexts within which proverbs are structured.

The representation of females in proverbs has been investigated both within individual languages, for instance, in Igbo (Oha 1998) and Kurdish (Rasul 2015), and cross-culturally, in order to highlight differences in perception; for instance, Rasul (2015) compared portrayal of women in English and Urdu proverbs from a socio-linguistic and critical discourse analysis perspective. Nabifar (2013) instead investigated the differences between English and Persian proverbs in relation to human cognitive system. Despite being unrelated, the scholar found common elements in both languages, suggesting similar mental mechanisms resting on a shared deeper structure. Chinese proverbs stereotypically depicting men and women were researched by Lee (2015) who discovered gender discrimination and male-'firstness' represented in them. However, the scholar also reported biased subjective approach of some linguists who mainly 'focused on the portrayal of women rather than men' (Lee 2015:562) in Chinese proverbs analysis.

\section{Functions of Proverbs}

This section will focus on the functions of proverbs, in particular on their nature and core aims of their use. Although there is no uniformity on the number of functions of proverbs, as well as their priority, scholars generally distinguish and agree on the following key functions: communicative, nominative, cognitive, cumulative, and modelling. A proverb is typically characterised by more than one function: however, and depending on the context in which it is used, there is always one that dominates. Communicative function of proverbs consists in message transmission in the communication process. That is, proverbs enclose information that is used if it fits the main communicative aim of the conversation.

The cognitive function of proverbs is a hotly debated subject. The question is whether 'proverbs should be accounted for by mental theories of proverbs comprehension or they should be considered a social phenomenon that can only be studied within its cultural matrix' (Buljan et al. 2013:63). Being wrapped in the 'cultural envelope' (Ibidem.), proverbs generate social meanings and regulate social behaviour of an individual in the society and on a large scale determine social consciousness of the nation that uses them. As Saussure observed, 'the culture of a nation exerts an influence on its language, and the language, on the other hand, is largely responsible for the nation' (Saussure 1959:20). Proverbs embrace cultural information, the spiritual world of a nation, its wisdom and world perception. They retain those social beliefs and values that have already disappeared with time and are carriers of social attitudes. This is the cumulative function of proverbs.

Further, among different functions of proverbs, the regulative one is essential - it supervises people's daily actions and it evaluated them either positively 
or negatively. Proverbs comprise social and cultural collective beliefs about the norms of gender qualities, attributes, roles, behaviour and their deviations. They vividly express the implications of gender stereotypes encrypted in languages and intended to directly influenced interlocutors. In other words, proverbs involve 'coordinating language with ways of acting, interacting, valuing, believing, feeling, and with bodies, clothes, non-linguistic symbols, objects, tools, etc.' (Gee 2000:25).

\section{Objective of the Study}

Based on the premise that proverbs describe and regulate roles of women in the community during their socialisation process, this paper focuses on the female positive and negative attributes reflected in Chinese proverbs and their implications on women's behaviour within the social settings.

\section{Research Questions}

a. what inner and outer attributes of women are reflected through the Chinese proverbs and their positive/negative connotations

b. what images and symbols are used in the Chinese proverbs to express female inner and outer attributes

\section{Data}

In pursuing the objective of the study, data comprising Chinese proverbs relating to female inner and outer attributes were collected from a range of dictionaries, published books and online sources (see: Literature Sources). They are presented thematically based on their meanings. By the end, over 1,000 Chinese proverbs were examined and 58 selected as pertinent for the analysis of female attributes within the Chinese cultural context.

\section{Theoretical Framework}

In this study, the Critical Discourse Analysis (CDA) as a theoretical framework is considered to be of particular significance. The choice of the approach is based on several factors. For a start, CDA conducts 'discourse analysis with attitude' (van Dijk 2001:96) that is, it allows 'better understanding and critique of social 
inequality, based on gender, ethnicity, class, origin, religion, language, sexual orientation and other criteria that define differences between people' (van Dijk 1997:22 - 23). Thus, applied to proverbs that express female attributes, CDA may uncover specificities and inequalities peculiar for social relationships, especially towards women in such gendered society as Chinese.

Next, the hallmark of CDA is that it can be combined with other approaches and disciplines related both to linguistics and social studies (van Dijk 2001). Thus, due to its multidisciplinary nature, CDA exploits three fundamental stages in this framework: description, interpretation, and explanation (Fairclough 2010:10-11).

In order to ascertain social beliefs, knowledge, and ethnic and gender prejudices towards women and womanhood in Chinese society represented in proverbs, CDA is combined with a socio-cognitive approach: this allows the analysis of proverbs in a broader, social framework and explore 'the relationship between discourse and the cognition of individuals' (van Dijk 1998). Further, group cognition serves as a 'collective memory bank' (Sharifian 2015:476), as if its members thought within a single consensual framework. Proverbs are believed to express the deeper meaning of life, a repository of ethno-cultural information expressing everything that belongs to the people as a kind of historical and anthropological record. Thus, in order to decode cultural elements within discourse referred to a network of shared values, norms, and beliefs within a given community (BarTal 2000; Gavriely-Nuri 2010 cited in Waugh et al. 2016:108), Gavriely-Nuri (2010) developed a cultural approach to critical discourse analysis (CCDA). This approach is sensitive to the uniqueness of proverbs in terms of the cultural information they contain. As Nida concurs, 'every language form we use has meanings, carries meanings that are not in the same sense because it is associated with culture and culture is more extensive than language' (Nida 1998). Furthermore, Brown states that 'a language is a part of a culture and a culture is a part of a language; the two are intricately interwoven so that one cannot separate the two without losing the significance of either language or culture' (Brown 1994).

\section{Description of Findings}

All the proverbs that express female attributes are divided into two main groups - inner and outer attributes which are further subdivided into smaller groups that present proverbs thematically based on their meaning. The group of inner attributes comprises Chinese proverbs that express obedience/submission, chastity, ignorance, modesty, industriousness, easy disposition, idleness, jealousy, talkativeness and anger whist the group of outer attributes includes beauty. At the same time, the attributes can be positively and/or negatively marked and mirror the attitude of the Chinese society towards the mentioned female characteristics. 
In order to gain a better understanding of the meanings and origin of the selected proverbs, and if necessary decode hidden information, it is essential to employ cultural, ethnographical, and historical sources of the Chinese language. Given that the focus of this work is not making general comments on proverbs but seeking to understand how they shape social gender models, this source-analysis approach may provide valuable clues to better address the key questions of this research.

\subsection{Positive Inner Attributes}

\subsubsection{Obedience / Submission}

In the Chinese culture, obedience is considered a positively-marked attribute of a woman and the selected proverbs in this sub-group elaborate the idea of model behaviour a Chinese woman has to follow:

(1) 嫁雞隨雞 嫁狗隨狗 (jià jī suí jī, jià gòu suí gǒu) 'Married to chicken follow chicken, married to dog follow dog' (Jiao et al. 2014:148);

(2) 夫以義為良掃以順為正 (fü zhì yǒ wéi liáng; fù yù shùn wéi chèng) 'In the husband fidelity is the thing that's good; in the wife obedience is the thing that's proper' (Scar. 1875:372);

(3) 夫唱婦隨 (fü chàng fù suí) 'Husband sings and wife follows / accompanies' (Scar. 1875:373);

(4) 在家由父貀嫁從夫 (tsài chīa yú fù; chū chià tsúng fū) 'Unmarried, a woman obeys her father; married, her husband' (Scar. 1875:242);

(5) 夫妻無隔夜之仇 (fū năi fù chīn tīen; chī năi fū chin nǘ) 'Husbands are as Heaven to their wives; wives are the slaves of their husbands' (Scar. 1875:377).

Historically, Chinese society has been strongly influenced by beliefs and values drawn from Confucianism. It became the official government's state philosophy during the Han dynasty $(206 \mathrm{BCE}-220 \mathrm{CE})$, and in particular during the time of Emperor $\mathrm{Wu}(141-87 \mathrm{BCE})$. Confucianism is based on the concept of relationship - 禮 as an ethical system rather than a religion $(l \grave{i})$. L L $\mathrm{i}$ were rules and norms of social behaviour that dictate the manner in which Chinese people position themselves within a hierarchical society and perform their roles accordingly. As stated in the philosophical tradition of Confucianism, there are 'five human relationships': sovereign and subject, father and son, elder and younger brother, friend and friend, and husband and wife. The last one is the first in origin and is of crucial importance, especially for a woman: 人倫有五夫婦為先. 大禮三千婚姻 最重 (jén lǘn yǔ wǔ fū fù wéi hsienen; tà lǐsān chīen hūn yīn tsùi chùng) 'There are 
Five Relations, but that of husband and wife stands first; there are three thousand great Rites, but that of marriage is most important' (Scar. 1875:372).

According to Confucius teaching, in order to maintain a strict social order, women should be subordinate to men at every level of social and family hierarchy: 'It is the law of nature that woman should be held under the dominance of man.' Typically, the latter can be described as 'patriarchal, patrilineal and patrilocal,' that is officially dominated by men (Stacey 1983:31).

Being a good woman in the Chinese feudal society could be hard given the strict standards of being 'good'. One of the basic moral principles for women in a family life in Confucianism is called 三从 (sān cóng) and rendered as 'three obediences'. The concept of the three obligations states that 'The woman follows (and obeys) the man; in her youth, she follows her father and elder brother; when married, she follows her husband; when her husband is dead, she follows her son (在家從父母 出嫁從丈夫 夫亡從子 (zài jiā cóng fù mǔ chū jià cóng zhàng fū fū wáng cóng zì)) (Adler 2006). Even the Chinese character 女 (nüu 'woman') traditionally depicts an outline of a woman kneeling on the floor, showing her obedience to a man (ShaoLan 2014:46). The ideal relationship between husband and wife is based on the instant respect represented in the proverb 举案齐眉 (jü àn qi méi) 'holding the tray up to the eyebrows.' The proverb originated in the belief that in order to demonstrate appreciation for husband, a wife should serve him food with her head bowed and holding the tray up to her eyebrows. With such gender-based inequality, Chinese mirror the inferiority of women in their marriage life in the proverbial wisdom (1), (2), (3).

During their lifetime, Chinese women were always economically dependent on two families - the natal one and marital home although they never completely belonged to either of them. As a result, female submissive behaviour was cultivated in the Chinese families since childhood and girls were prepared for such long-adopted social norm of transferring to the husband's family. It is proverbially represented in (4).

Some proverbs portray men as owners of their wives and the right to display brutal attitude towards them - (5). In the light of this, gender inequality became a customary part of a family daily life. Domestic violence was considered necessary to forestall problems and ensure tranquillity. It was a means to ensure a woman's subordinance and obedience to her husband:

強婆娘只怕打 (chiàng pó niáng chǐh pà tă) 'nothing will brighten a wilful wife but a beating' (Scar. 1875:377);

女人如手推車若三日不打則不能用 (nü rén rú shǒu tū chē, ruò sān rì bù dă zé bù néng yòng) 'Women are like wheelbarrows; if not beaten for three days they cannot be used' (Scar. 1875:377). 


\subsubsection{Vertude - General}

This group embraces the following proverbs that describe Chinese society's attitude to female and her general virtuosity:

(8) 女德無極.婦怨無終 (nü té wú chí; fù yǜn wú chùng) 'A maid's virtue is unlimited; a wife's resentment without end' (Scar. 1875:378);

(9) 忠臣不事二君.貞婦不事二夫 (chūng chén pù shì èrh chün; chēn fù pù shì èrh fü) 'A loyal minister will serve but one Prince; a virtuous woman but one husband' (Scar. 1875:378);

(10) 家有賢妻.男人不遭橫事 (chīa yǔ hsiēn chī, nán jén pù tsāo hùn shìh) 'A virtuous wife saves her husband from evil ways' (Scar. 1875:377);

(11) 娶媳求淑女.勿討厚㗊 (chü hsì chiú shú nǘ, wù chì hòu lién) 'In marrying a son seek a virtuous maiden, and scheme not for a rich dowry' (Scar. 1875:370);

(12) 賢婦令夫貴. 惡婦令夫賤 (hsién fü ling fū kuèi, ò fù ling fü chièn) 'A virtuous wife causes her husband to be honoured; a bad one brings him to shame' (Scar. 1875:377);

(13) 癡漢怕老婆. 賢女敬丈夫 (chíh hàn pà lăo pó; hsien nü chìng chàng $f \bar{u})$ 'The fool fears his old woman; but the virtuous wife reverences her husband' (Scar. 1875:374);

(14) 娶妻不在美貌. 賢德便好 (chü chī pù tsài yén sè, hsién té pien hăo) 'The excellence of a wife consists not in her beauty, but in her virtue' (Scar. 1875:63).

According to Confucian beliefs, it is essential for a girl to be virtuous and enjoy a good reputation: failing would lead to 'shame' and social disgrace. Chinese proverbially praise virtuous women stating they are a serious moral support to husbands - (8), (9), (10), (11), (12), (13), (14). Chastity is one of the main criterions in choosing a bride. That is, initially, a man should care about his bride's and/ or wife's virtue instead of her appearance. It is noteworthy that in Chinese culture the emphasis on pre-marital abstinence and virginity also results in a continuous sex segregation, which is one of the characteristics of traditional Chinese gender culture rooted in the concept of chastity. Proverbially it is expressed in

(15) 冰清玉潔 (bing qìng yù jié) 'As clean as ice and as pure as jade' meaning 'pure and noble, being a virgin' (DOCCIE 2010:159).

By comparing a girl's chastity to jade, the proverb stresses its preciousness since in Chinese culture jade is a highly treasured gem. It represents goodness and physical attractiveness and is another symbol of beauty. 
If a girl violated the rule and lost her virginity before marriage she was strongly condemned by the society and given offensive, pejorative names (e.g. 破 鞋 (pò xié) 'broken shoe,' that is a 'loose woman') (Mair 2012).

\subsubsection{Vertude - Aspirational}

This sub-group incorporates proverbs expressing female positive attributes that women in Chinese society should aspire to and model their lives accordingly. Moreover, as it is clearly depicted in the enduring proverbial wisdom, Chinese set certain standards as guidance for a man and his family in choosing suitable brides. These criteria are known as 四德 (sì dé) or 'Four Virtues' that consist of 妇德 ( fù dé) 'morality', 妇言 (fù yán) 'proper speech', 妇容 (fù róng) 'modest manner/appearance', and 妇功 (fù gōng) 'diligent work.' It is a formed moral code of great value which is significant and widely recognised even nowadays:

(16) 婦德者 不必才名絕異 (fù té ché pù pì tsái ming chüeh i) 婦容者 不必顏色美麗 (fù yúng ché pù pì yén sè mèi lì) 婦言者 不必利口辨詞 (fù yén ché pù pì lì kóu pien tzú) 婦工者 不必技巧過人 ( fü kūng ché pù pì chì chiăo kùo jén)

'A woman's virtues need not to be of the famous or uncommon kind; her face need not very beautiful; her conversation need not be very eloquent; and her work need not be very exquisite or surpassing' (Scar. 1875:244).

Modesty and easy-going personality were highly prioritised among attributes young ladies should be equipped as in:

(17) 窈毞淑女君子好述 (yăo tiăo shū nü, jūn zì hào qiú) 'Modest, retiring young ladies are sorted by gentlemen' (Chen 1981:520);

(18)下氣小心䋓是婦女 (hsì chì hsiăo hsìn tsái shìh fù nü) 'Good tempered and careful - she's a good wife indeed' (Scar. 1875:378).

In the patriarchal Chinese society, for centuries ignorance was considered a woman's virtue and was a positive attribute:

(19) 女子無才便是德 (nüzǐ wú cái biàn shì dé) 'Ignorance is a woman's virtue' (DOCCIE 2010:66).

Such positive public perception of ignorant females is explained by different societal expectations and family roles of husband and a wife. As confirmation to this, 'men outside, women inside' 男主外.女内 (nán zhǔ wài nü rǔ nèi) is a relationship model generally widely accepted in China which resulted in gender stereotypes. The deep-seated belief persisted that the proper place for a woman was at home, where she was largely responsible for the upbringing and education 
of children and doing household chores: 侍奉箕帚 (shì fèng jī zhǒu) 'to perform wifely duties (cooking and cleaning)'. According to Yu and Xie (2012) report, family labour division is based on gender stereotyping with the lion's share falling on the shoulders of the wife rather than a husband (Xie 2013).

\subsection{Negative Inner Attributes}

This sub-group includes proverbs that describe negative female attributes according to the Chinese societal and cultural convictions. Generally, a woman's greatest challenge is an elementary one: surviving in a family. In her struggle for survival and achieving dominance in a hierarchical Chinese family, a woman used available feminine negative 'attributes' such as jealousy and anger, to assert her authority. However, a woman had to be careful in using these so-called 'weapons' giving that socially inappropriate behaviour might be interpreted as possessing evil powers and bringing bad luck to the family. The unwanted result could be divorce and utter shame for the woman. Proverbially, it is stated that negative features are peculiar for most women:

(20) 十個婦人九個妒 (shì kò fù jén chŭu kò tù) 'Nine women in ten are jealous' (Scar. 1875:241).

There is a unique proverb in Cantonese to express the utmost level of jealousy experienced by a woman:

(21) 呷醋 (haap3 cou3) ‘Sip vinegar' (DOCCIE 2010:116).

It is said that in the Tang Dynasty, the emperor sent his powerful prime minister a beautiful girl to be his concubine. Although polygyny was an accepted practice in ancient China, his jealous wife would rather drink poison than accept another woman in her marriage. The emperor, touched by her courage and love, secretly filled a vial with vinegar and bade her to drink. After gulping down the liquid and surviving, the story spread and people began using the term 吃醋 $(c h \bar{l} c \grave{u})$ to refer to someone jealous of their lover.

In Chinese proverbs, laziness, talkativeness and anger are other clichéd negative attributes of femininity, which are strongly disliked:

(22) 懶婆娘做事一担挑 (lăn pó niàng tsò shì jī tān tiāo) 'Lazy women will try to carry everything at once' (Scar. 1875:242)

(23) 懶女人盼新年 (lăn nü̈rén pàn xīn nián) 'Lazy woman looks forward to the New Year' (DOCCIE 2010:153) 
Violent-tempered, angry women were represented through the animalistic code and associated with venomous, vicious, and carnivorous creatures (snake, tigress, fighting cock):

(24) 青竹蛇兒口貝蜂尾上針.兩般不算毒区最毒婦人心 (chīng chú shé érh kŏu, huáng fēng wěi shàng chēn. lĭang pān pù suàn tú, tsùi tú fü jén hsīn) 'There is no such poison in the green snake's mouth or the hornet's sting, as in a woman's heart' (Scar. 1875:243);

(25) 老虎姆 (lou5 fu2 naa2) lit. 'A tigress; one's shrewish wife' (Cantonese) (DOCCIE 2010:67);

(26) 倀/撐雞 (caang4 gail) lit. 'Be like a fighting cock; be shrewish' (Cantonese) (DOCCIE 2010:159);

(27) 倀/撐雞妹 (caang4 gail muil) lit. 'A girl like a fighting cock; a girl of passionate disposition and violent temper' (Cantonese) (DOCCIE 2010:159);

(28) 惡揗揗 (ok3 tan 4 tan4) ‘Look ferocious’(Cantonese) (DOCCIE 2010:194).

\subsection{Outer attributes}

As for the group of female outer attributes expressed in Chinese proverbs, there is just beauty that is prioritised for a woman, although declined only through a few specific details, such as complexion and poise (grace). It signifies that inner qualities are of higher importance for a woman in the Chinese society.

\subsubsection{Beauty}

As it was mentioned earlier, marriages in Chinese families were always organised by parents based on the social status and prosperity of the candidates and, obviously, no feelings of love or sympathy were taken into consideration. Nevertheless, if the girl was physically attractive she had a chance to marry into money, get status in the social hierarchy and lead a relatively 'easier' life. Thus, beautiful girls were mostly preferred by the potential 'wealthy' husbands.

Taking into consideration the concept of beauty and its criteria that exists in the social consciousness of the Chinese proverbs analysed in this work, we conclude that beauty is one of the fundamental characteristics of a woman, her key outer attribute. It takes her life to a new level and sometimes assigns a new meaning. Beauty is considered to be generally acceptable and it can be equally appreciated by the representatives of various age categories as well as national, racial and ideological groups. One of the main features of beauty is that it can be detected in any of the temporal and spatial dimensions, in different historical and social conditions. 
In ancient China, there were four women who left a large footprint in the long course of history. One of them was Xi Shi 西施 (497 BC) - a legendary beauty of ancient China whose attractiveness was said to be so outstanding that when she leaned over a balcony to look at the fish in the pond $-\ldots$ the fish would be so dazzled that they forgot to swim and sank away from the surface, thus winning her the title of 'the one who sinks the fishes': 沉魚 (chén yú), means 'sank fish'. ${ }^{1}$ It is exemplified by a Chinese proverb used to compliment someone's beauty:

(29) 沉魚落雁 (chén yú luò yàn), which literally means 'fish sink and goose alights' (TDPC 2014).

It is indeed noteworthy that feminine beauty in the Chinese linguistic community is portrayed as a powerful and mighty attribute. Proverbially, the stunning beauty of a woman is endowed with a destructive force that is capable of capturing cities and states:

(30) 一笑傾人城.再笑傾人國 (ȳ̄ hsiào chūn zhén chéng; tsài hsiào chūn zhén kóu) 'With one smile she overthrows a city; with another, a kingdom' (Scar. 1875:244-245);

(31) 傾國傾城 (qing guó qing chéng) (about an exceedingly beautiful woman) 'Lovely enough to cause the fall of a state and the collapse of a city' (Jiao et al. 2011:104).

However, it is interesting to note that the Chinese judged a girl's physical attributes using very stringent parameters before calling her a beauty:

(32) 品頭論足 (p̌̀n tóu lùn zú) 'Criticise head and feet' means 'make critical remarks about a woman' physical appearance trying to find fault' (Jiao et al. 2011:97).

Eventually, feminine beauty is fleeting and short-lived, as evidenced by the following proverbs - peculiar warnings for young beauties that are verbalised in the Chinese language:

(33) 紅顏易老 (hóng yán yì lăo) ‘Pretty face easily turns old’(Chen 1981:160).

Indeed, a proverb reveals a negative attitude towards women who are no longer young, but who are still trying to attract the opposite sex by comparing them to Lady $\mathrm{Xu}$, a famous concubine of Emperor Yuan of the Liang Dynasty:

1 西施 (Xi Shi) - A Chinese beauty's legend, 18 July 2012. Retrieved from: http://lang-8. com/276806/journals/1584822. 
(34) 半老徐娘 (bàn lăo xú niáng) 'Flirtations of a middle-aged woman who still remains traces of her erstwhile beauty' (Jiao et al. 2011:130).

It is known that every culture defines physical attractiveness using specific aesthetic standards. Here we consider some of them in Chinese culture and highlight their language representations.

According to tradition, there are several types of beauty. The Chinese use the proverb 燕瘦環肥 (yàn shòu húan féi), which means 'Yáng Yùhuán was plump while Zhaò Feiyàn was skinny', to describe the range in terms of physical size. The idiom mentions Empress Xiaocheng (孝成皇后), Emperor Cheng's empress during the Han Dynasty who was often compared and contrasted with Yang Guifei, the beautiful concubine of Emperor Xuanzong of Tang and one of the four Chinese beauties, because she was known for her slender build while Yang was known for her full build. Despite the difference in their physique, they both were considered enticing. That is, the proverb means that every beautiful woman is attractive in her own way. ${ }^{2}$

It is worth mentioning that in ancient times, a woman's stoutness showed the well-being and social status of her family. It meant she did not do any heavy manual job, could afford better and tastier food and, respectively, was considered attractive and was called

(35) 秀色可餐 (xiù sè kè cān) 'Beauty that is the feast of the eye' (Jiao et al. 2011:130).

Indeed, two other Chinese beauties, namely Xi Shi 西施 and Yang Guifei 楊玉 環, were both weighty and ample. However, slim and graceful women were also believed to be beautiful:

(36) 婷婷玉立 (ting ting yù li) ‘slim and graceful’ (Jiao et al. 2011:117).

Another Chinese proverb relates to different beauty criteria, so that a fair-complexioned, rich, and pretty single female in her twenties or thirties is extolled as

(37) 白富美 (bái fù méi) lit. 'white [not ethnically] - wealthy - beautiful') (DOCCIE 2010:201).

Many Chinese people believe the white skin colour makes a woman look more attractive and beautiful. This idea is expressed in an ancient Chinese saying:

${ }^{2}$ English translation for “環肥燕瘦”. Retrieved from: http://en.ichacha.net/chinese-english/\%E7\% $8 \mathrm{E} \% \mathrm{AF} \% \mathrm{E} 8 \% 82 \% \mathrm{~A} 5 \% \mathrm{E} 7 \% 87 \% 95 \% \mathrm{E} 7 \% 98 \% \mathrm{~A} 6$. 
(38) 一白遮百醜 (ȳi bai zhè bai chŏu) which in the English equivalent is A white complexion is powerful enough to hide seven faults (faults in your body type, face, demeanour and many others). ${ }^{3}$ It means no matter what flaws your appearance has, but if your skin is of white colour - you are a beauty.

Delineating attractive woman's appearance Chinese tend to appeal to the auspicious symbols in their culture. For instance, Chinese often compare physically attractive and elegantly dressed women to flowers and actualise the phytonimic images of hibiscus and lotus:

(39) 芙蓉 (蓮花) 出水 (fú róng (lián huā) chū shuì) 'Hibiscus (lotus) rises out of water' (Jiao et al. 2011:47);

(40) 出水芙蓉 (chū shuǐ fú róng) 'As a lotus flower breaking the surface' talking about a young lady's face that is surpassingly beautiful (TDPC 2014).

In Chinese culture the hibiscus symbolises glory, fame, splendour and lotusflower is a sacred Buddhist symbol of the evolution. In Chinese culture, lotus symbolises ultimate purity and perfection because it rises untainted and beautiful from the mud (Doré 1918).

Traditionally, the Chinese have often associated the Moon with female beauty deriving their inspiration from the lunar natural cycle. It is till today one of the most prominent and potent symbols amongst the huge body of Chinese characters. The Moon is associated thus with gentleness and brightness:

(41)纖繶月 (qīan qĩan yuè) 'as graceful as the new moon' (Jiao et al. 2011:231);

(42) 花容月貌 (huā róng yuè mào) lit. 'Countenance of a flower, face like the moon' (TDPC 2014).

In some Chinese proverbs, the semantics of beauty is greatly hyperbolised to show its exclusivity, mighty impact and impossibility to resist:

(43) 閉月羞花 (bì yuè xiū huā) lit. 'Hiding the moon, shaming the flowers' meaning fig. 'female beauty exceeding even that of the natural world' (TDPC 2014);

(44) 國色天香 (guó sè tiān xiāng) lit. 'National grace, divine fragrance' (TDPC 2014);

3 Cultural Semantic and "Illusory Correspondence", 2014, Donghua University. Retrieved from: http://www.zhuanyilunwen.com/pass/ywxz_1324_5453.html. 
(45) 絕代佳人 (jué dài jiā rén) lit. 'Beauty unmatched in her generation' (TDPC 2014);

(46) 絕世佳人 (jué shi jiā rén) lit. 'A woman of unmatched beauty.' (TDPC 2014);

(47) 軍得一陣 (wan4 dak1 jat1 zan6) lit. 'Faint away for a while' and 'be intoxicated by one's beauty' (Cantonese) (DOCCIE 2010:218);

(48) 英雄難過美人關(yinngxióng nán guò měirén guān) lit. 'Hero-difficultgo through-beautiful-person-pass' meaning that no man can resist the charms of a beautiful woman (Jiao et al. 2014:51).

In the analysed Chinese proverbs beauty is not only positively but also negatively marked. It is interesting to note that being beautiful does not necessarily lead to a happy and easy life:

(49) 紅顏薄命 (hóng yán bó ming) lit. 'beautiful women suffer unhappy fates' (TDPC 2014);

(50) 紅顏女子多薄命.聰明子弟少容顏 (húng yén nü tzǔ tō pó mìng, tsūng míng tzǔ tì shăo yúng yén) 'Fair ladies are very unlucky, and clever young men have little beauty' (Scar. 1875:242).

Indeed, a beautiful woman in the house may be a source of problems (according to proverbs, of course) for her husband and other family members, generating negative feelings such as jealousy and envy:

(51) 好女于室. 醜女之仇 (hăo nú yú shìh, chǒu nǘ chīh chóu) 'A good-looking woman in a house, is the foe of all the plain ones' (Scar. 1875:244).

Moreover, there is an additional 'danger' that she could be associated with misfortune and evil. Proverbs strongly warn men against marrying attractive girls:

(52) 醜婦拙奴無價之寶 (chŏu chī chù̀eh nü̃ wú chìa chīh păo) 'Ugly wives and stupid maids are priceless treasures' (Scar. 1875:377);

(53) 妻妾切忌豐妝 (chī chièh chièh chì yèn chuāng) 'Do not marry wives or concubines who are gorgeously fine' (Scar. 1875:377);

(54) 不要觀音面. 只要夫星現 (pù yào kuān yīn mièn; chìh yào fū hsīng hsien) 'Long not for the goddess' beauty divine; long that the star of your husband may shine' (Scar. 1875:370);

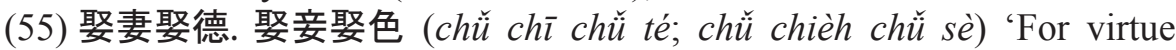
a woman our wife we make; for her beauty we a concubine take' (Scar. 1875:370). 
At the same time, clearly depicted in the proverbial wisdom, if a man is in love the appearance of his beloved appears flawless, the most attractive and elegant to him. Such is claimed in these Cantonese proverbs:

(56) 各花入各眼 (gok3 faal lok6 gok3 ngaan5) 'Every flower falls to every man's eye' (DOCCIE 2010:85);

(57) 冤豬頭都有盟鼻菩薩 (jyun1 zyul tau4 dou1 jau5 mang4 bei6 pou4 saat 3 ) 'A foul pig's head would be appreciated by the god with bad nose' (DOCCIE 2010:168).

In some cases, a lover would compare his woman to the apex of beauty herself, Xi Shi:

(58) 情人眼裏出西施 (qíng rén yăn lǐ chūx xī shī) lit. 'In the lover's eye, there is Xi Shi' (Chen 1981:327; Jiao et al. 2014:16).

\section{Discussion}

Female attributes expressed in the Chinese proverbs are classified in Table 1. They are divided into two groups - inner attributes and outer attributes. We find that the number of the inner female attributes represented in proverbs greatly outweigh those based on outer attributes. Further, inner female attributes are clearly either positively or negatively marked, offering a clear moral and behavioural guide for women within the Chinese society. The positive 'inner attributes' include obedience/submission, virtuousness, chastity, ignorance, modesty, industriousness and easy disposition whilst negative female attributes are jealousy, envy, anger, talkativeness and idleness.

It was observed that in the Chinese proverbs, negative female attributes like anger and hot temper are represented through animalistic images where women, for instance, are compared to venomous, vicious and carnivorous creatures (snake, tigress, fighting cock, etc.).

In regards to the 'outer attributes' group, it is important for a woman to possess an attractive physical appearance, although the detailed attributes are rarely mentioned, for instance the relative size of her feet (relevant in ancient Japanese culture for instance). Indeed, 'beauty' is a concept seldomly addressed in detail but often elevated to an idealistic perfection and compared to beautiful inanimate objects (flowers, jade, the Moon, etc.). Body size does not appear to characterise the aesthetic rating of a woman (both 'thin' and 'large' are regarded as attractive), except for the more common association of 'grace' and elegance with a slender figure.

An unblemished skin of pale complexion is highly regarded since it both embodies 'purity' and chastity (as per inner attributes) but it also implies limited 
time exposure to the elements, to general manual work carried out outdoors, in particular farming (thus, an indicator of higher society status).

However, unlike much of the European Romantic tradition, beauty is considered as a potential obstacle towards a blessed marital life, generating envy in the household from other female members and potentially attracting unwelcome attention from other males outside. Further, a beautiful wife would not probably be as industrious and submissive as a less self-assured female. Therefore, some proverbs, with more than a hint of malice and humour, 'advise' men to seek beauty and grace outside the wedlock, from concubines and lovers.

\section{Conclusions}

Proverbs are known to carry a cultural and social legacy which is handed down from generation to generation in virtue to the useful function they perform in encapsulating complex concepts relating to everyday life concisely and, often, humorously. They also give even obnoxious or controversial ideas an aura of ancient wisdom and authority.

An investigation of proverbs that express female attributes in the Chinese society revealing social beliefs, ethnic and gender prejudice towards women, as well as accumulated ethno-cultural information, was carried out through a combination of critical discourse analysis and socio-cognitive approaches.

The picture that emerges from the analysis of these traditional Chinese proverbs is symptomatic of strict patriarchal civilisations common all over the world, but with an 'aesthetic twist' (e.g., skin tone, body size). A woman is either 1) an idealised object of beauty, akin to natural wonders, and so powerful and dangerous with her beauty to bring down whole kingdoms on her wake, or 2) a humble (wedded) and unintelligent servant who should be seen but not heard whilst carrying out loyal duties towards her (male) master and his direct family.

Further studies should look at the evolution and relevance of some of these proverbs in modern Chinese culture, and if they still apply to a modern society where women are quickly catching up with gender equality, both politically (21.3\% of the National People's Congress of China, although still only $16.6 \%$ in the Standing Committee - NPCC, Zheng, Guo \& Zhao 2009:10) and in the society at large $\left(55 \%\right.$ of all entrepreneurs in China are female, ${ }^{4}$ though no CEOs of the largest companies). ${ }^{5}$

${ }^{4}$ Retrieved from: http://www.womenofchina.cn/womenofchina/html1/special/Beijing_world_conference_on_women/1509/2321-1.htm.

5 http://fortune.com/2015/07/22/china-global-500-government-owned/. 
Table 1: Female attributes as expressed in Chinese proverbs

\begin{tabular}{|c|c|c|c|}
\hline \multicolumn{3}{|c|}{ Woman } \\
\hline inner attributes & \multicolumn{2}{c|}{ outer attributes } \\
\hline positive & negative & positive & negative \\
\hline obedience/submission & jealousy & \multicolumn{2}{c|}{ body size } \\
\hline virtuousness & envy & grace & \\
\hline chastity & anger & pale completion & \\
\hline ignorance & talkativeness & & 'too attractive' \\
\hline modesty & idleness & & \\
\hline industriousness & hot temper & & \\
\hline easy disposition & & & \\
\hline
\end{tabular}

\section{References}

AdLer Joseph A., 2006, Daughter/Wife/Mother or Sage/Immortal/Bodhisattva? Women in the Teaching of Chinese Religions, in: ASIANetwork Exchange XIV(2). Retrieved from http:// www2.kenyon.edu

BAR-TAL Daniel, 2000, Shared beliefs in a society: Social psychological analysis, Thousand Oaks. BHUVANESWAR Chilukuri, 2015, The Proverb and Its Definition: A Karmik Linguistic Approach, in: Grandl C./Mckenna K.J. (eds.), Bis dat, qui cito dat, Frankfurt am Main.

BRown Douglas H., ${ }^{3}$ 1994, Principles of Language Learning and Teaching, Englewood Cliffs, NJ.

BULJAN Gabrijela / GRADEČAK-ERDELJÍ Tanja, 2013, Where cognitive linguistics meets paremiology: a cognitive-contrastive view of selected English and Croatian proverbs, in: Explorations in English Language and Linguistics 1(1), pp. 63-83.

Cultural Semantic and "Illusory Correspondence", 2014, Donghua University. Retrieved from http://www.zhuanyilunwen.com/pass/ywxz_1324_5453.html

DomingUEZ Barajas Elías, 2010, Function of proverbs in discourse: The case of Mexican transnational social network, in: Series - Contributions to the Sociology of Language 98, USA.

DoRÉ Henry S. J., 1918, Researches into Chinese Superstitions, Kennelly M. S. J. (trans.), Shanghai. English translation for “環肥燕瘦”. Retrieved from http://en.ichacha.net/chinese-english/\%E7\%8E $\% \mathrm{AF} \% \mathrm{E} 8 \% 82 \% \mathrm{~A} 5 \% \mathrm{E} 7 \% 87 \% 95 \% \mathrm{E} 7 \% 98 \% \mathrm{~A} 6$

FAIRCLOUgH Norman, ${ }^{2} 2010$, Critical Discourse Analysis. The Critical Study of Language, Harlow. GAVRIELY-NURI Dalia, 2010, The idiosyncratic language of Israeli 'peace': A cultural approach to Critical Discourse Analysis (CCDA), in: Discourse \& Society 21, London, pp. 565 - 585

GEE James Paul, 2000 , An introduction to Discourse Analysis: Theory and Method: 话语分析入 门: 理论与方法, Routledge.

Goodwin Paul D. / Wenzel Joseph W., 1981, Proverbs and Practical Reasoning: A Study in SocioLogic, in: Mieder W./Dundes A. (eds.), The wisdom of many. Essays on the proverb,, New York, pp. $140-160$.

GuO Xiajuan / ZHAO Litao, 2009, Women's Political Participation in China, EAI Background Brief No. 453.

HONECK Richard P. / KIBLER Clare T., 1984, The Role of Imagery, Analogy, and Instantiation in Proverb Comprehension, in: Journal of Psycholinguistic Research 13(6), Springer, pp. $393-414$. 
KEMPER Susan, 1981, Comprehension and the interpretation of proverbs, in: Journal of Psycholinguistic Research 10(2), Springer, pp. 179-198.

LEE Fung King Jackie, 2015, Chinese Proverbs: How are Women and Men Represented? in: GÉNEROS - Multidisciplinary Journal of Gender Studies 4(1), pp. 559-585.

LIEBER Michael D., 1984, Analogic Ambiguity: A Paradox of Proverb Usage, in: Journal of American Folklore 97, pp. $423-441$.

MAIR Victor, 6 August 2012, Chinese terms of address for single ladies. Retrieved from http://languagelog.ldc.upenn.edu/nll/?p=4116.

MiEDER Wolfgang, 2004, Sociology, Psychology and Psychiatry, in: Mieder W., Proverbs: A Handbook, Westport/ CT \& Oxford, pp. $139-142$.

Mieder Wolfgang, 2008, It Pays to Proverbialize: Folk Wisdom in the Modern Mass Media, in: Mieder W., "Proverbs Speak Louder Than Words": Folk Wisdom in Art, Culture, Folklore, History, Literature and Mass Media, New York, pp. $121-141$.

NABIFAR Nesa, 2013, A Comparative Study of English and Persian Proverbs on Basis of Cognitive Linguistics, in: Technical Journal of Engineering and Applied Sciences. Retrieved from http:// epu.edu.krd/images/researches/Final_Female_Humiliation.pdf.

NIDA Eugene, 1998, Language, culture, and translation, in: Foreign Languages Journal 115(3), pp. $29-34$.

OHA Obododimma, 1998, The Semantics of Female Devaluation in Igbo Proverbs, in: African Study Monographs 19(2), pp. 87-102.

PALtRIDGe Brian, 1994, Genre Analysis and the Identification of Textual Boundaries, in: Applied Linguistics 15(3), pp. $288-299$.

PASAMANICK Judy, 1985, Watched pots do boil: Proverbs interpretation through contextual illustration, in: Proverbium 2, pp. 145-183.

RASUl Sarwet, 2015, Gender and Power Relationships in the Language of Proverbs: Image of a Woman, in: FWU Journal of Social Sciences 5(2), pp. 53-62.

DE SAUSSURE Ferdinand, 1916 (1959), A Course in General Linguistics, in: Bally C./Sechehaye A. (eds.), in collaboration with Reidlinger A. (Translated from the French by Baskin W.), New York.

ShaoLAN Hsueh, 2014, Chineasy: The New Way to Read Chinese, United Kingdom.

SHARIFIAN Farzad, 2015, Cultural Linguistics, in: The Routledge Handbook of Language and Culture, Routledge, pp. 473-492.

SHEDROVITSKY Georgy P. / RozIN Vadim M., 1967, Concept of linguistic relativity of B.L. Uorf's and research problems of language thinking, in: Semiotics and East Languages, Moscow.

StACEY Judith, 1983, Patriarchy and Socialist Revolution in China, Berkeley, Los Angeles/London.

TAYLOR Archer, 1996, The Collection of the Study of Proverbs, in: De Proverbio. Electronic journal of international proverb studies, proverbs, quotations, sayings, wellerisms 2(2). Retrieved from http://www.deproverbio.com/Dpjournal/DP,2,2,96/PROBLEMS.html.

Traduction de Proverbes Chinois (Expressions et Chengyu), 2014. Retrieved from http://www. regine-traduction.com/proverbes-chinois.php.

TYLER Andrea, 1994, The role of syntactic structure in discourse structure: Signaling logical and prominence relations, in: Applied Linguistics 15(3), pp. 243-262.

Waugh Linda R. / Catalano Theresa / Masaeed Khaled Al / Do Tom Hong / Reginar Paul G., 2016, Critical Discourse Analysis: Definition, Approaches, Relation to Pragmatics, Critique, and Trends, in: Interdisciplinary Studies in Pragmatics, Culture and Society, Capone A./ Mey J.L. (eds.), Springer.

VAN DIJK Teun, 1997, The study of discourse, in: van Dijk T.A. (ed.) Discourse studies: A multidisciplinary introduction, vol. 1: Discourse as structure and process, London, pp. 1-34.

VAN DIJK Teun, 2001, Multi-disciplinary CDA: a plea for diversity, in: Wodak R./Meyer M. (eds.), Methods of Critical Discourse Analysis, London and Thousand Oaks, CA, pp. 1-13. 
VAN DIJK Teun, 2013, Ideology: A multidisciplinary approach, London, Sage 1998 cited in The Routledge Linguistics Encyclopedia, Malmkjær K. (ed.), London /New York, p. 124.

YanKah Kwesi, 1994, Do Proverbs Contradict? in: Mieder W. (eds.), Wise Words: Essays on the Proverb, New York, pp. 127-142.

YU Jia / Xie Yu, 2012, The Varying Display of 'Gender Display', in: Chinese Sociological Review 44(2), pp. $5-30$.

XIE Yu, October 2013, Gender and Family in Contemporary China. University of Michigan, in: Population Studies Center Research Report 13-808.

西施 (Xi Shi) - A Chinese beauty's legend, 18 July 2012. Retrieved from http://lang-8.com/276806/ journals/1584822.

\section{List of sources}

CHEN 1981 - Chen Yong-zhen, 1981, Chinese Idioms and Their English Equivalents, Hong Kong. DOCCIE 2010 - A Dictionary of Cantonese Colloquialisms in English, 2010, Hong Kong.

JIAO et al. 2011 - Jiao Liwei / Kubler Cornelius C. / Zhang Weiguo, 2011, 500 Common Chinese Idioms. An annotated Frequency Dictionary, Routledge.

JiAO et al. 2014 - Jiao Liwei / Stone Benjamin M., 2014, 500 Common Chinese Idioms. An annotated Frequency Dictionary, New York: Routledge.

SCAR. 1875 - Scarborough William, 1875, A Collection of Chinese Proverbs, Shanghai: American Presbyterian Mission Press.

TDPC 2014 - Traduction de Proverbes Chinois (Expressions et Chengyu), 2014. Retrieved from http://www.regine-traduction.com/proverbes-chinois.php.

\section{Internet websites}

http://www.womenofchina.cn/womenofchina/html1/special/Beijing_world_conference_on_ women/1509/2321-1.htm.

http://fortune.com/2015/07/22/china-global-500-government-owned/. 